\title{
DERADIKALISASI DALAM PENANGGULANGAN \\ TINDAK PIDANA PERSPEKTIF UNDANG-UNDANG \\ TERORISME DI INDONESIA
}

\author{
Samud \\ Fakultas Syari'ah dan Ekonomi Islam \\ Institut Agama Islam Negeri Syekh Nurjati Cirebon \\ Jl. Perjuangan By Pass Sunyaragi Cirebon \\ Email :Samudra686@gmail.com
}

\begin{abstract}
Abstrak
Deradikalisasi mempunyai cakupan makna yang luas, mulai dari hal-hal yang bersifat keyakinan, penanganan hukum, hingga pemasyarakatan sebagai upaya mengubah "yang radikal" menjadi "tidak radikal". Namun secara sederhana, deradikalisasi dapat dipahami sebagai upaya menetralisir paham radikal bagi mereka yang terlibat aksi terorisme dan para simpatisannya, hingga para teroris atau para simpatisannya meninggalkan aksi kekerasan. Pengertian deradikalisasi seperti ini sangan jauh dari tendensi untuk memojokan agama tertentu. Karena radikalisme bias tumbuh di dalam umat agama manapun. Teror telah hadir dan menjelma dalam kehidupan kita sebagai momok, sebagai virus ganas dan monster yang menakutkan yang sewaktu-waktu tidak dapat diduga bisa menjelmakan terjadinya "prahara nasional dan global", termasuk mewujudkan tragedi kemanusiaan, pengebirian martabat bangsa dan penyejarahan tragedi atas Hak Asasi Manusia (HAM). Hak Asasi Manusia (HAM) kehilangan eksistensinya dan tercerabut kesucian atau kefitriannya di tangan pembuat teror yang telah menciptakan kebiadaban berupa aksi animalisasi (kebinatangan) sosial, politik, budaya, dan ekonomi.
\end{abstract}

Kata Kunci: Deradikalisasi, Penanggulangan Tindak Pidana, dan Undang-Undang Terorisme

\begin{abstract}
Deradicalization has a wide range of meanings, starting from matters of belief, legal handling, to correctionalization as an effort to change "radical" to "non-radical". But in simple terms, deradicalization can be understood as an effort to neutralize radicalism for those who are involved in acts of terrorism and their sympathizers, so that the terrorists or their sympathizers leave the violence. This definition of deradicalization is far from the tendency to corner certain religions. Because radicalism can grow in any religious community. Terror has been present and incarnated in our lives as a scourge, as a vicious virus and frightening monster which at times can not be expected to manifest "national and global catastrophes", including realizing human tragedies, castration of national dignity and the tragedy of human rights tragedy. (HAM). Human Rights (HAM) lost their existence and were deprived of their sanctity or finesse at the hands of terrorists who had created outrage in the form of social, political, cultural, and economic animalization.
\end{abstract}

Keywords: Deradicalization, Combating Crime, and Terrorism Law 


\section{A. Pendahuluan}

Setiap manusia membutuhkan kedamaian, kecukupan, dan kemakmuran yang terkadang sulit untuk didapat atau bahkan tidak jarang kondisi sebaliknya yaitu peperangan, kekerasan, kekurangan, dan kemiskinan tak terhindarkan. Keadaan yang demikian banyak ditemui di negara berkembang. Perkembangan teknologi dan ilmu pengetahuan di negara maju yang berdampak pada peningkatan skala kemakmuran kehidupan di negara maju seringkali menimbulkan kecemburuan pada negara berkembang. Globalisasi dan pasar bebas adalah sedikit contoh ketidakseimbangan sebuah kompetisi kehidupan rakyat negara maju dan berkembang yang menimbulkan kekecewaan dan rasa ketidakadilan yang sifatnya diskualifikatif, dislokatif, dan deprivatif secara sosio-ekonomis dan politis. $^{1}$

Terorisme merupakan suatu tindak pidana atau kejahatan luar biasa yang menjadi perhatian dunia sekarang ini terutama di Indonesia. Terorisme yang terjadi di Indonesia akhir-akhir ini memiliki keterkaitan ideologis, sejarah dan politis serta merupakan bagian dari dinamika lingkungan strategis pada tataran global dan regional. Kendatipun aksi terorisme yang terjadi di berbagai daerah dalam beberapa tahun terakhir ini kebanyakan dilakukan oleh orang Indonesia dan hanya sedikit aktor-aktor dari luar. Namun tidak dapat dibantah bahwa aksi terorisme saat ini merupakan suatu gabungan antara pelaku domestik dengan mereka yang memiliki jejaring trans-nasional. $^{2}$

Dalam rangka mencegah dan memerangi Terorisme tersebut, sejak jauh sebelum marakanya kejadian-kejadian yang digolongkan sebagai bentuk

\footnotetext{
${ }^{1}$ Ali Masyhar, Gaya Indonesia Menghadang Terorisme, (Bandung: CV. Mandar Maju, 2009), .1.

2 Muhammad A.S. Hikam, Deradikalisasi: Peran Masyarakat Sipil Indonesia Membendung Radikalisme, (Jakarta: PT Kompas Media Nusantara, 2016), . 33-34.
}

terorisme terjadi di dunia, masyarakat internasional maupun regional serta berbagai negara telah berusaha melakukan kebijakan kriminal (criminal policy) disertai kriminalisasi secara sistematik dan komprehensif terhadap perbuatan yang dikategorikan sebagai Terorisme. ${ }^{3}$

Bukan sekedar aksi teror semata, akan tetapi pada kenyataannya tindak pidana terorisme juga melanggar hak asasi manusia sebagai hak dasar yang secara kodrat melekat dalam diri manusia yaitu hak untuk hidup dan hak untuk merasa aman dan nyaman. Pengakuan terhadap hak asasi manusia merupakan salah satu perwujudan dari konsep negara hukum yang diatur di dalam ketentuan Pasal 1 ayat (3) UUD 1945. Sebelum amandemen terhadap UUD 1945, pengakuan atas hak asasi manusia diatur di dalam ketentuan Pasal 28 UUD 1945. Sedangkan setelah atau pasca amandemen terhadap UUD 1945, pengaturan mengenai hak asai manusia semakin diperjelas dan diperinci sebagaimana yang diatur di dalam Pasal 28 dan Pasal 28A-28J UUD 1945.

Dalam mengupayakan pemenuhan dan perlindungan hak asasi warga dari tindak kejahatan terorisme maka pemerintah Indonesia merasa perlu untuk membentuk Undang-Undang Pemberantasan Tindak Pidana Terorisme, yaitu dengan menyusun Peraturan Pemerintah Pengganti Undang-Undang (Perpu) Nomor 1 Tahun 2002. Yang pada tanggal 4 April 2003 disahkan menjadi Undang-Undang RI dengan Nomor 15 Tahun 2003 tentang Pemberantasan Tindak Pidana Terorisme. ${ }^{4}$

Salah satu hal yang melatarbelakangi lahirnya Undang-Undang tersebut adalah

\footnotetext{
${ }^{3}$ Muladi, Hakekat Terorisme dan Beberapa Prinsip Pengaturan dalam Kriminalisasi, tulisan dalam Jurnal Kriminologi Indonesia FISIP UI, Vol II No. 03 Desember 2002, Hal. 1.

${ }^{4}$ Romli Atmasasmita dan Tim, Analisis dan Evaluasi Peraturan Perundang-Undangan tentang Pemberantasan Tindak Pidana Terorisme (Undang-Undang Nomor 15 tahun 2003), (Jakarta: Badan Pembinaan Hukum Nasional Kementerian Hukum dan Hak Asasi Manusia, 2012), . 73.
} 
tragedi bom di Sari Club dan Paddy's Club Kuta Legian Bali 12 Oktober 2002, yang selayaknya digolongkan sebagai kejahatan terbesar di Indonesia dari serangkaian teror yang ada. Tragedi tersebut adalah sebuah bukti nyata bahwa teror adalah aksi yang sangat keji yang tidak memperhitungkan, tidak memperdulikan dan sungguhsungguh mengabaikan nilai-nilai kemanusiaan. Manusia yang tidak tahu menahu akan maksud, misi atau tujuan pembuat teror telah menjadi korban tidak berdosa (innocent victim). Rakyat tidak berdosa hanya menjadi ongkos kebiadaban manusia yang tidak dimenangkan dan tidak disupremasikan aksi teror yang terjadi di Legian Bali. Hal itu mengingatkan publik pada kejadian black Tuesday (selasa kelabu), yaitu peristiwa pengeboman yang telah menghancurkan simbol kapitalisme Negara Adikuasa AS berupa Menara World Trade Center (WTC) dan simbol pertahanan AS, Pentagon. Publik global menarik benang merah bahwa tragedi Bali dan kasus WTC AS adalah produk gerakan kelompok terorisme yang bermaksud merusak kedamaian global, menghancurkan nilai-nilai peradaban dan mendagrasikan HAM.

\section{B. Tindak Pidana Terorisme Sebagai Extra Ordinary Crime}

\section{Radikalisme dan Terorisme}

Istilah radikalisme tidak jarang dimaknai berbeda diantara kelompok kepentingan. Dalam lingkup kelompok keagamaan, radikalisme merupakan gerakan-gerakan keagamaan yang bersusaha merombak secara total tatanan sosial dan politik yang ada dengan menggunakan jalan kekerasan. ${ }^{5}$ Radikalisme agama bertolak dari gerakan politik yang mendasarkan diri pada suatu doktrin keagamaan yang paling fundamental secara penuh dan literal bebas dari kompromi, penjinakan dan

\footnotetext{
${ }^{5}$ A. Rubiadi, Radikalisme Islam, Nahdatul Ulama Masa Depan Moderatisme Islam di Indonesia, (Yogyakarta: Logung Pustaka, 2007), . 33.
}

reinterprestasi (penafsiran). ${ }^{6}$ Sedangkan dalam studi ilmu sosial radikalisme diartikan sebagai pandangan yang ingin melakukan perubahan yang mendasar sesuai dengan interpretasinya terhadap realitas sosial atau ideologi yang dianutnya. Berdasarkan telaah arti radikalisme tersebut, radikalisme sesungguhnya merupakan konsep yang netral dan tidak bersifat pejorative (melecehkan). Karena perubahan yang besifat radikal bisa dicapai melalui cara damai dan persuasive, tetapi bisa juga dengan kekerasan. ${ }^{7}$

Menurut Afdlal menyatakan bahwa fundamentalisme dilihat sebagai pemahaman tentang perlunya kembali ke dasar agama dan menggunakan dasar-dasar tersebut sebagai penuntun kehidupan masyarakat. ${ }^{8}$ Oleh karena itu, makna radikalisme tidak tunggal tetapi tergantung konteksnya. Dalam kontek terorisme maka radikalisme jelas merupakan kekerasan. Namun dalam konteks pemikiran atau gagasan maka radikalisme bukan merupakan kekerasan, sehingga tidak menjadi persoalan sejauh tindak diikuti oleh tindakan kekerasan. Secara teoritik menjelaskan bagaimana pergeseran dari radikalisme menjadi terorisme yang bergerak dari konsep fanatisme dan radikalisme. Dalam mengekspresikan fanatisme dan radikalisasi bisa muncul dalam berbagai bentuk. Tetapi pada umumnya berbanding lurus dengan reaksi dan atau sikap dari kelompok lawan. Aksi dan reaksi antara dua kelompok berhadapan mungkin berbeda, namun pada umumnya mendekati derajat dan pola yang hampir sama. Kekerasan akan dilawan dengan kekerasaan, dan salah satu

\footnotetext{
${ }^{6}$ Azyumardi Azra, Memahami Gejala Fundamentalisme, Jurnal Ulumul Qur'n, No. 3 Vol. IV 1993,. 5.

${ }^{7}$ Ismail Hasani dan Bonar Tigor Naipospos, Radikalisme Agama di Jabotabek dan Jawa Barat: Implikasinya Terhadap Jaminan Kebebasan Beragama/Berkeyakinan, (Jakarta: Pustaka Msyarakat Stara, 2010), . 19.

${ }^{8}$ Afdal dkk, Islam dan Radikalisme di Indonesia, (Jakarta: LIPI Press, 2005), . 19.
} 
bentuknya bisa berwujud gerakan terorisme. ${ }^{9}$

Sedangkan istilah teror dan terisme sudah ada sejak lama, yakni pada masa Imperium Romawi pada paruh awal abad pertama Masehi yang pada saat itu diperintah Tiberius dan Caligula. Selain itu, pada abad ke-17 kerajaan-kerajaan di Eropa, khususnya Spanyol menekan organisasi-organisasi islam dengan ancaman kekerasan, untuk mengikuti kemauan dari kerajaan atau keluar dari tanah Andalusia. Namun demikian, meskipin bersifat konvensional, istilah teror dan terorisme baru mulai populer pada abad ke-18. Berkaitan dengan itu, El Saadawi menyatakan bahwa terorisme bukanlah hal yang baru. Terorisme terjadi sepanjang masa, yang dipelihara dan dikembangbiakan oleh ketidakadilan dan penindasan, dan berkaitan dengan ekstremisme rasial, seks, politik atau agama dan terkadang merupakan kombinasi lebih dari ekstremisme. Namun demikian, bentuk terorisme belakangan ini lebih tampak sebagai sesuatu berkaitan dengan fundamentalisme agama. ${ }^{10}$

Kata "teroris" dan "terorisme" berasal dari kata Latin "terrere" yang kurang lebih berarti membuat gemetar atau menggetarkan. Kata "teror" juga dapat menimbulkan kengerian. ${ }^{11}$ Terorisme merupakan suatu kejahatan yang tidak dapat digolongkan sebagai kejahatan biasa, secara akademis terorisme dikategorikan sebagai kejahatan luar biasa (extra ordinary crime) dan dikategorikan pula sebagai kejahatan terhadap kemanusiaan atau "crime against humanity". Mengingat kategori yang demikian maka pemberantasannya tentulah tidak dapat

\footnotetext{
${ }^{9}$ Afdal dkk, Islam dan Radikalisme di Indonesia, . 9 .

10 Budi Gunawan, Terorisme, Mitos dan Konspirasi, (Jakarta: Forum Media Utama, 2006), . 3-4.

${ }^{11}$ Abdul Wahid, Kejahatan Terorisme Perspektif Agama, HAM dan Hukum, (Bandung: Rafika Aditama, 2002), . 22.
}

menggunakan cara-cara biasa. ${ }^{12}$ Terorisme sebagai suatu fenomena sosial mengalami perkembangan seiring dengan perkembangan peradaban manusia. Caracara yang digunakan untuk melakukan kekerasan dan ketakutan juga semakin canggih seiring dengan perkembangan teknologi modern. Proses globalisasi dan budaya massa menjadi lahan subur perkembangan terorisme.

Terorisme adalah paham yang berpendapat bahwa penggunaan cara-cara kekerasan dan menimbulkan ketakutan adalah cara yang sah untuk mencapai tujuan. ${ }^{13}$ Dengan demikian menurut Nasir Abas, bahwa teror merupakan reaksi jahat yang dipandang "lebih jahat" oleh pelaku, sehingga bukan merupakan kejahatan yang berdiri sendiri (interactionism) dan dapat dikelompokkan kedalam kejahatan balas dendam (hate crimes). ${ }^{14}$ Terorisme dapat diartikan sebagai penggunaan atau ancaman penggunaan kekerasan fisik yang direncanakan, dipersiapkan, dan dilancarkan secara mendadak terhadap sasaran langsung, yang lazimnya adalah non combatant untuk mencapai suatu tujuan politik. Pengertian terorisme dalam rumusan yang panjang dikemukakan oleh James Adams, yaitu: ${ }^{15}$

"Terorisme adalah penggunaan atau ancaman kekerasan fisik oleh individuindividu atau kelompok-kelompok untuk

\footnotetext{
${ }^{12}$ Keterangan pemerintah tentang diterbitkannya Undang-Undang Nomor 1 Tahun 2002 tentang Pemberantasan Tindak Pidana Terorisme dan Peraturan Pemerintah Pengganti Undang-Undang Nomor 2 Tahun 2002 tentang Pemberantasan Tindak Pidana Terorisme, Departemen Kehakiman dan Hak Asasi Manusia, Pada Peristiwa Peledakan Bom di Bali Tanggal 12 Oktober 2002, . 8 .

${ }^{13}$ Muchamad Ali Syafaat, Terorisme, Definisi, Aksi dan Regulasi, . 60

${ }^{14}$ Nasir Abas, Kajian Tentang Terorisme, Makalah pada Diskusi Kajian tentang Terorisme di Ditjentarahan Kemenkumham, Jakarta, 16 Januari 2002,. 1 .

${ }^{15}$ Pendapat James Adam sebagaimana dikutip Samela Victor Mohamad, Terorisme dan Tata Dunia Baru, (Jakarta: Pusat Pengkajian dan Pelayanan Informasi Sekretariat Jenderal DPR-RI, 2002), . 106.
} 
tujuan-tujuan politik, baik untuk kepentingan atau untuk melawan kekuasaan yang ada, apabila tindakantindakan terorisme itu dimaksudkan untuk mengejutkan, melumpuhkan atua mengintimidasi suatu kelompok sasaran yang lebih besar daripada korban-korban langsungnya. Terorisme melibatkan kelompok-kelompok yang berusaha untuk menumbangkan rezim-rezim tertentu untuk mengoreksi keluhan kelompok/nasional, atau untuk menggerogoti tata politik internasional yang ada".

Menurut Hafid Abbas, terorisme adalah pemakaian keuatan atau kekerasan tidak sah melawan orang atau properti untuk mengintimidasi atau menekan suatu pemerintahan, masyarakat sipil, atau bagian-bagiannya, untuk memaksakan tujuan sosial atau politik. ${ }^{16}$ Pengertian tindak pidana terorisme menurut Pasal 1 angka 1 UU No. 15 Tahun 2003, adalah: "Tindak Pidana Terorisme adalah suatu perbuatan yang memenuhi unsur-unsur tindak pidana sesuai dengan ketentuanketentuan dalam undang-undang". Sedangkan dalam Pasal 5 UU No. 15 Tahun 2003, mengatur hal yang menarik dan bersifat khusus, yaitu: "Tindak Pidana Terorisme dikecualikan dari tindak pidana politik, tindak pidana yang berkaitan dengan tindak pidana politik, tindak pidana dengan motif politik, dan tindak pidana dengan tujuan politik, yang menghambat proses ekstradisi". Ketentuan yang tercantum dalam Pasal 5 UU No. 15 Tahun 2003 tersebut dimaksudkan agar tindak pidana terorisme tidak dapat berlindung di balik latar belakang, motivasi, dan tujuan politik untuk menghindarkan diri dari penyidikan, penuntutan, pemeriksaan di sidang pengadilan dan penghukuman terhadap pelakunya. Ketentuan ini juga untuk meningkatkan efisiensi dan efektifitas perjanjian ekstradisi dan

16 Hafid Abbas, Beyond Terrorism: Perspektif Indonesia, (Jakarta: Pustaka Sinar Harapan, 2002), . 3. bantuan hukum timbal balik dalam masalah pidana antara Pemerintah Republik Indonesia dengan pemerintah negara lain.

Indonesia dan berbagai negara di dunia sesungguhnya telah berkeinginan untuk melakukan kriminalisasi terhadap perbuatan terorisme jauh sebelum terjadinya peristiwa 11 September 2001 yang menghancurkan World Trade Centre di New York, Amerika Serikat dan peledakan bom di Kuta Bali tanggal 12 Oktober 2002. Kedua peristiwa tersebut dilakukan dengan menggunakan kekerasan atau ancaman kekerasan terhadap keselamatan jiwa manusia tanpa pandang bulu terhadap korbannya. Terorisme merupakan kejahatan luar biasa (extra ordinary crime) yang membutuhkan pula penanganan dengan mendayagunakan cara-cara luar biasa (extra ordinary measure). Sehubungan dengan hal tersebut Muladi mengemukakan: ${ }^{17}$

"Setiap usaha untuk mengatasi terorisme, sekalipun dikatakan bersifatdomestik karena karakteristiknya mengandung elemen "etno socio or religios identity", dalam mengatasinya mau tidak mau harusmempertimbangkan standar-standar keluarbiasaan tersebut denganmengingat majunya teknologi komunikasi, informatika dan transportasimodern. Dengan demikian tidaklah mengejutkan apabila terjadi identitasterorisme lintas batas negara (transborder terorism identity)".

Sejalan dengan itu Romli Atmasasmita, mengatakan bahwa dari latar belakang sosiologis, terorisme merupakan kejahatan yang sangat merugikan masyarakat baik nasional maupun internasional, bahkan sekaligus merupakan perkosaan terhadap hak asasi manusia Masyarakat Indonesia yang bersifat multi etnik dan multi agama, terdiri dari ratusan

\footnotetext{
${ }^{17}$ Muladi, Hakekat Terorisme dan Beberapa Prinsip Pengaturan dalam Kriminalisasi, tulisan dalam Jurnal Kriminologi Indonesia FISIP UI, Vol II No. 03 Desember 2002, Hal. 1. .
} 
suku pulau dan terletak di antara dua benua (Asia dan Australia) merupakan sasaran yang sangat srategis kegiatan terorisme. Dalam menghadapi terorisme di Indonesia Romli Atmasasmita, menyatakan: ${ }^{18}$

"Dengan mempertimbangkan latar belakang filosofis, sosiologis dan yuridis diperlukan suatu perangkat perundangundangan yang memiliki visi dan misi serta terkandung prinsip-prinsip hukum yang memadai sehingga dapat dijadikan penguat bagi landasan hukum bekerjanya sistem peradilan pidana di mulai dari tingkat penyidikan sampai pada pemeriksaan di sidang pengadilan. Undang-undang tersebut harus dapat mencerminkan nilai-nilai yang berkembang dan diperlukan masyarakat dan bangsa Indonesia baik pada masa kini maupun pada masa mendatang, dan sekaligus juga dapat mencerminkan nilainilai yang berlaku universal dan diakui masyarakat internasional".

Terorisme merupakan kejahatan terorganisir yang beroperasi atau melakukan aksinya dalam hubungan secara internasional, berdasarkan kebangsaan, agama, rasa atau ideologi politik. Pada umumnya mereka dibiayai, dilatih dan dikendalikan agen di luar negara, di mana mereka beroperasi. Sebagai hasil dalam kolaborasi internasional mereka, insiden teroris telah berkembangsangat menghawatirkan dalam beberapa tahun belakangan ini.Usaha pemberantasan tindak pidana terorisme dengan ketiga tujuan tersebut di atas menunjukan bahwa bangsa Indonesia adalah bangsa yang menjunjung tinggi peradaban umat manusia dan memiliki cita perdamaian dan mendambakan kesejahteraan serta memiliki komitmen yang kuat untuk tetap menjaga keutuhan wilayah negara kesatuan

${ }^{18}$ Romli Atmasasmita, Kasus Terorisme Di Indonesia Berdasarkan Undang-Undang Nomor 15 Tahun 2003 Tentang Pemberantasan Tindak Pidana Terorisme, Makalah pada Seminar Penanganan Terorisme Sebagai Tindak Pidana Khusus, Jakarta 28 Juni 2004, . 1-2.
Republik Indonesia yang berdaulat di tengah-tengah gelombang pasang surut perdamaian dan keamanan dunia.

\section{Tindak Pidana Terorisme}

Terorisme merupakan bencana yang dibuat manusia (man made disaster). Pada umumnya, terorisme berbentuk tindak kekerasan terorganisasi (organized crime) yang dilakukan sekelompok orang untuk mengejar tujuan-tujuan politik. Sebagai suatu alat politik, dalam sejarahnya, teror telah digunakan oleh pihak tertindas maupun yang menindas. Salah satu pihak sudah biasa menyebut sekutunya yang melakukan teror sebagai pejuang pembebasan dan menyebut pihak lain sebagai teroris atau sabotir. Secara filosofis, Budi Hardiman mengatakan bahwa teror bersumber dari kematian. Dalam segala objektivitas sebab-sebab ataupun akibat-akibatnya, teror adalah pengalaman subjektif, karena setiap orang memiliki ambang ketakutan masingmasing. Semua orang takut mati, tetapi ketakutan itu berbeda-beda, tidak hanya menurut subjeknya, tetapi juga situasinya. Ketakutan akan mati tidak hanya bisa dihilangkan, tetapi juga bisa diperbesar. Teknik ini disebut teror danterorisme adalah politik kematian. ${ }^{19}$

Peledakan bom merupakan salah satu modus pelaku terorisme yang telah menjadi fenomena umum di beberapa negara. Terorisme merupakan kejahatan lintas negara, terorganisir, dan bahkan merupakan tindak pidana Internasional yang mempunyai jaringan luas, yang mengancam perdamaian dan keamanan nasional maupun internasional. Pemerintah Indonesia sejalan dengan amanat sebagaimana ditentukan dalam Pembukaan UUD 1945 yakni melindungi segenap bangsa Indonesia dan seluruh tumpah darah Indonesia, memajukan kesejahteraan umum, mencerdaskan kehidupan bangsa dan ikut serta dalam memelihara ketertiban dunia yang berdasarkan kemerdekaan dan

\footnotetext{
${ }^{19}$ F. Budi Hardiman, Memahami Negativitas: Diskursus tentang Massa, Teror, dan Trauma, (Jakarta: Kompas, 2005), . 55.
} 
perdamaian abadi dan keadilan sosial, berkewajiban untuk melindungi warganya dari setiap ancaman kejahatan baik bersifat nasional maupun bersifat internasional. Pemerintah juga berkewajiban untuk mempertahankan kedaulatan serta memelihara keutuhan dan integritas nasional dari setiap bentuk ancaman baik yang datang dari luar maupun dari dalam. Untuk itu, maka mutlak diperlukan penegakan hukum dan ketertiban secara konsisten dan berkesinambungan.

Tindak pidana terorisme merupakan tindak pidana yang dalam hukum pidana Belanda memakai istilah strafbaar feit, kadang-kadang juga delict yang berasal dari bahasa Latin delictum. Hokum pidana Negara-negara Anglo Saxon memakai istilah offense atau criminal act untuk maksud yang sama. Oleh karena itu, KUHP Indonesia bersumber pada WvS Belanda, maka istilah aslinya pun sama yaitu strafbaar feit. Sekarang ini semua UU telah memakai istilah tindak pidana. ${ }^{20}$ Usaha menanggulangi tindak pidana terorisme memerlukan kerja keras dari Pemerintah Indonesia melalui aparat penegak hukumnya dan peran serta masyarakat untuk mencegah dan menanggulangi tindak pidana terorisme. Menurut Sudarto tindak pidana merupakan suatu pengertian dasar dalam hukum pidana dan juga merupakan suatu pengertian yuridis. Istilah tindak pidana dipakai sebagai pengganti "strafbaar feit" dan hingga saat ini pembentuk UU senantiasa menggunakan istilah tindak pidana dalam peraturan perundangundangan. Secara dogmatif masalah pokok yang berhubungan dengan hukum pidana ada tiga hal, yaitu: ${ }^{21}$

a. Perbuatan yang dilarang;

b. Orang yang melakukan perbuatan yang dilarang itu; dan

\footnotetext{
${ }^{20}$ Andi Hamzah, Asas-Asas Hukum Pidana, (Jakarta: Rineka Cipta, 2008), . 86.

${ }^{21}$ Sudarto, Hukum Pidana I, (Semarang: Badan Penerbit Universitas Diponegoro, 1990), . 38-39.
}
c. Pidana yang diancamkan terhadap pelanggar itu.

Perbuatan pidana adalah perbuatan yang dilarang oleh suatu aturan hokum larangan mana disertai ancaman (sanksi) yang berupa pidana tertentu, bagi barangsiapa melanggar larangan tersebut. Dapat juga dikatakan bahwa perbuatan pidana adalah perbuatan yang oleh suatu aturan hukum dilarang dan diancam pidana, asal saja dalam pada itu diingat bahwa larangan ditujukan kepada perbuatan, (yaitu suatu keadaan atau kejadian yang ditimbulkan oleh kelakuan orang), sedangkan ancaman pidananya ditujuakan kepada orang yang menimbulkannya kejadian itu. ${ }^{22}$ Menurut Simons, bahwa strafbaar feit(terjemahan harafiah: peristiwa pidana) ialah perbuatan melawan hokum yang berkaitan dengan kesalahan (schuld) seseorang yang mampu bertanggungjawab. Kesalahan yang dimaksud oleh Simons ialah kesalahan dalam arti luas yang meliputi dolus (sengaja) dan culpa late (alpa dan lalai). Dari rumusan tersebut Simons, mencampurkan unsur-unsur perbuatan pidana yang meliputi perbuatan dan sifat melawan hokum perbuatan dan pertanggungjawaban pidana (criminal liability) yang mencakup kesengajaan, kealpaan serta kelalaian dan kemampuan bertanggungjawab. ${ }^{23}$ Tindak pidana atau delik ialah tindak yang mengandung lima unsur, yaitu: ${ }^{24}$
a. Harus ada sesuatu kelakuan (gedraging);
b. Kelakuan itu harus sesuai dengan uraian undang- undang (wettelijke omschrijving);
c. Kelakuan itu adalah kelakuan tanpa hak;

\footnotetext{
${ }^{22}$ Moeljatno, Asas-Asas Hukum Pidana, (Jakarta: Rineka Cipta, 2002), . 54.

${ }^{23}$ Zainal Abidin, Hukum Pidana I, (Jakarta: Sinar Grafika, 2007), . 224.

${ }^{24}$ C.S.T. Kansil dan Cristine S.T. Kansil, Pokok-Pokok Hukum Pidana, (Jakarta: Pradnya Paramita, 2007), . 37.
} 

d. Kelakuan itu dapat diberatkan kepada pelaku; dan
e. Kelakuan itu diancam dengan hukuman.

Tindak pidana terorisme adalah perbuatan yang memenuhi unsur-unsur tindak pidana dalam UU No. 15 Tahun 2003. Menurut Simons, menyebutkan adanya unsur objektif dan unsur subjektif dalam strafbaar feit, yaitu:

a. Unsur Objektif dari strafbaar feit, adalah:

1) Perbuatan orang;

2) Akibat yang kelihatan dari perbuatan itu; dan

3) Keadaan tertentu yang menyertai perbuatan itu.

b. Unsur subyektif dari strafbaar feitadalah:

1) Orang yang mampu bertanggung jawab; dan

2) Adanya kesalahan (dolus atau culpa).

Unsur-unsur tindak pidana terorisme yang terdapat dalam UU No. 15 Tahun 2003 akan dibahas dalam dua bagian yaitu: kesatu, unsur-unsur tindak pidana terorisme, dan kedua, tindak pidana yang berkaitan dengan tindak pidana terorisme.

Pasal 6 UU No. 15 Tahun 2003 di atas, termasuk dalam "delik materiel" yaitu yang ditekankan pada akibat yang dilarang yaitu hilangnya nyawa, hilangnya harta, atau kerusakan dan kehancuran. Sedangkan yang dimaksud dengan kerusakan atau kehancuran lingkungan hidup adalah tercemarnya atau rusaknya kesatuan semua ruang dengan semua benda, daya, keadaan, dan makhluk hidup termasuk manusia dan perilakunya, yang mempengaruhi kelangsungan perikehidupan dan kesejahteraan manusia serta makhluk lainnya. Terorisme memiliki beberapa ciriyang mendasar, dan antara lain: kegiatan terorisme dilakukan dengan cara-cara kekerasan (contoh pengeboman, penyanderaan, dan lain-lain) untuk memaksakan kehendaknya, dan cara tersebut merupakan sebagai sarana (bukan merupakan tujuan), sasaran serangannya adalah tempat-tempat umum atau objek vital seperti pusat-pusat perbelanjaan, bandara, stasiun. Korbannya pun tidak dipilih-pilih, dan kegiatannya sangat profesional untuk dilacak jejaknya.

Tindak pidana terorisme sebagai tindak pidana khusus sebagai UU khusus, berarti UU No. 15 tahun 2003 mengatur secara materiel dan formil sekaligus, sehingga terdapat pengecualian dari asas yang secara umum diatur dalam Kitab Undang-Undang Hukum Pidana (KUHP) atau Kitab Undang-Undang Hukum Acara Pidana (KUHAP) "lex specialis derogat lex generalis". Keberlakuan lex specialis derogat lex generalis, harus memenuhi kriteria: ${ }^{25}$

a. Bahwa pengecualian terhadap undang-undang yang bersifat umum, dilakukan oleh peraturan yang setingkat dengan dirinya, yaitu undangundang; dan

b. Bahwa pengecualian termaksud dinyatakan dalam undang-undang khusus tersebut, sehingga pengecualiannya hanya berlaku sebatas pengecualian yang dinyatakan dan bagian yang tidak dikecualikan tetap berlaku sepanjang tidak bertentangan dengan pelaksanaan undang-undang khusus tersebut.

Sedangkan kriminalisasi Tindak Pidana Terorisme sebagai bagian dari perkembangan hukum pidana dapat dilakukan melalui banyak cara, seperti:

\footnotetext{
${ }^{25}$ Sudikno Mertokusumo, Mengenal Hukum, Suatu Pengantar, (Yogyakarta: Liberty, 1996), . 85-87.
} 
a. Melalui sistem evolusi berupa amandemen terhadap pasal-pasal KUHP;

b. Melalui sistem global melalui pengaturan yang lengkap di luar KUHP termasuk kekhususan hukum acaranya; dan

c. Sistem kompromi dalam bentuk memasukkan bab baru dalam KUHP tentang kejahatan terorisme.

Akan tetapi tidak berarti bahwa dengan adanya hal yang khusus dalam kejahatan terhadap keamanan negara berarti penegak hukum mempunyai wewenang yang lebih atau tanpa batas semata-mata untuk memudahkan pembuktian bahwa seseorang telah melakukan suatu kejahatan terhadap keamanan negara, akan tetapi penyimpangan tersebut adalah sehubungan dengan kepentingan yang lebih besar lagi yaitu keamanan negara yang harus dilindungi. Demikian pula susunan babbab yang ada dalam peraturan khusus tersebut harus merupakan suatu tatanan yang utuh. Selain ketentuan tersebut, pasal 103 KUHP menyebutkan bahwa semua aturan termasuk asas yang terdapat dalam Buku I KUHP berlaku pula bagi peraturan pidana di luar KUHP selama peraturan di luar KUHP tersebut tidak mengatur lain. ${ }^{26}$ Hukum Pidana khusus, bukan hanya mengatur hukum pidana materielnya saja, akan tetapi juga hukum acaranya, oleh karena itu harus diperhatikan bahwa aturan-aturan tersebut seyogyanya tetap memperhatikan asas-asas umum yang terdapat baik dalam ketentuan umum yang terdapat dalam KUHP bagi hukum pidana materielnya sedangkan untuk hukum pidana formilnya harus tunduk terhadap ketentuan yang terdapat dalam UndangUndang Nomor 8 Tahun 1981 tentang

\footnotetext{
${ }^{26}$ Loebby Loqman, Analisis Hukum dan Perundang-undangan Kejahatan Terhadap Keamanan Negara di Indonesia, (Jakarta: Universitas Indonesia Press, 1990), . 26.
}

Kitab Undang-Undang Hukum Acara Pidana (KUHAP). ${ }^{27}$

\section{Terorisme Sebagai Kejahatan \\ Luar Biasa (Extraordinary Crime)}

Pandangan teroretis tersebut jelas menggambarkan bagaimana relasi antara terorisme dan radikalisme, yang terbukti antara lain dari fakta bahwa sejumlahkasus terorisme yang melibatkan individu, kelompok atau bahkan organisasi yang dipandang memiliki faham radikal. Dalam kasus serangan terorisme yang terjadi di gedung menara kembar World Trade Center (WTC) Amerika Serikat pada 11 September Tahun 2001, misalanya Amerika Serikat menjadikan Osama bin Laden dengan kelompoknya Al Qaeda yang berafaham radikal sebagai tertuduh pelaku di balik serangan tersebut. Demikian pula terhadap serangan terorisme di Indoensia. Dari kasus Bom Bali terdapat pelaku seperti Abdul Aziz alias Imam Samudra alias Qudama yang dipandang memiliki faham radikal. ${ }^{28}$

Kejahatan terorisme merupakan salah satu bentuk kejahatan berdimensi internasional yang sangat menakutkan masyarakat. Di berbagai negara di dunia telah terjadi kejahatan terorisme baik di negara maju maupun negara-negara sedang berkembang, aksi-aksi teror yang dilakukan telah memakan korban tanpa pandang bulu. Hal ini menyebabkan Perserikatan Bangsa Bangsa (PBB) dalam kongresnya di Wina Austria tahun 2000 mengangkat tema The Prevention of Crime and The Treatment of Offenders, antara lain menyebutkan terorisme sebagai suatu perkembangan perbuatan dengan kekerasan yang perlu mendapat perhatian. Menurut Muladi, terorisme merupakan kejahatan luar biasa (extraordinary crime)

\footnotetext{
${ }^{27}$ Loebby Loqman, Analisis Hukum dan Perundang-undangan Kejahatan Terhadap Keamanan Negara di Indonesia, (Jakarta: Universitas Indonesia Press, 1990), .149.

${ }^{28} \mathrm{Ali}$ Masyhar, Gaya Indonesia Menghadang Terorisme, (Bandung: CV. Mandar Maju, 2009),... 4.
} 
yang membutuhkan pula penanganan dengan mendayagunakan cara-cara luar biasa (extraordinary measure) karena berbagai hal: ${ }^{29}$
a. Terorisme merupakan perbuatan yang menciptakan bahaya terbesar (the greatest danger) terhadap hak asasi manusia. Dalam hal ini hak asasimanusia untuk hidup (the right to life) dan hak asasi untuk bebas dari rasa takut;

b. Target terorisme bersifat random atau indiscriminate yangcenderung mengorbankan orang-orang tidak bersalah;
c. Kemungkinan digunakannya senjata-senjata pemusnah massal dengan memanfaatkan teknologi modern;
d. Kecenderungan terjadinya sinergi negatif antar organisasi teroris nasional dengan organisasi internasional;

e. Kemungkinan kerjasama antara organisasi teroris dengan kejahatan yangterorganisasi baik yang bersifat nasional maupun transnasional;

f. Dapat membahayakan perdamaian dan keamanan internasional.

Terorismesebagai kejahatan telah berkembang menjadi lintas negara.

Kejahatan yang terjadi di dalam suatu negara tidak lagi hanya dipandang sebagai yurisdiksi satu negara tetapi bisa diklaim termasuk yurisdiksi tindak pidana lebih dari satu negara. Menurut Romli Atmasasmita, dalam perkembangannya kemudian dapat menimbulkan konflik yurisdiksi yang dapat mengganggu

\footnotetext{
${ }^{29}$ Muladi, Hakekat Terorisme dan Beberapa Prinsip Pengaturan dalam Kriminalisasi, tulisan dalam Jurnal Kriminologi Indonesia FISIP UI, Vol II No. 03 Desember 2002, Hal. 1. .
}

hubungan internasional antara negaranegara yang berkepentingan di dalam menangani kasus-kasus tindak pidana berbahaya yang bersifat lintas batas territorial. Kejahatan terorisme menggunakan salah satu bentuk kejahatan lintas batas negara yang sangat mengancam ketentraman dan kedamaian dunia. ${ }^{30}$ Indonesia sebagai negara hukum, dalam penegakan hukum terhadap tindak pidana tertentu khususnya tindak pidana terorisme sangat mengutamakan landasan peraturan perundang-undangan yang bercirikan kepastian hukum dan keadilan.Pemberlakuan UU No. 15 Tahun 2003, semakin menampakan kelemahankelemahannya ketika diterapkan dalam praktek di lapangan.

Makna terorisme mengalami pergeseran dan perluasan paradigma yaitu sebagai suatu perbuatan yang semula dikatergorikan sebagai crime againt statesekarang meliputi terhadap perbuatanperbuatan yang disebut sebagai crime againt humanitydimana yang menjadi korban adalah masyarakat yang tidak berdosa, semuanya dilakukan dengan delik kekerasan (kekerasan sebagai tujuan), kekerasan (violence) dan ancaman kekerasan (threat of violence).Adanya suatu feeling for fear atau intimidating to public and governmentalyang tujuan akhirnya adalah berkaitan dengan delik politik, yaitu melakukan perubahan sistem politik yang berlaku dalam suatu negara. Dampak yang demikian luas akibat tindakan terorisme, maka perlu dilakukan upaya-upaya untuk melindungi warganegara dan kepentingan negara dengan membuatrambu-rambu hukum nasional, salah satu cara dengan meratifikasi perkembangan hukum international tentang penanggulangan tindakan terorisme. ${ }^{31}$

\footnotetext{
${ }^{30}$ Romli Atmasasmita, Pengantar Hukum Pidana Internasional, (Bandung: Rafika Aditama, 2000), . 58.

${ }^{31}$ Romli Atmasasmita, dkk, Naskah Akademik Perubahan UU No. 15 Tahun 2003, (Jakarta: BPHN, 2011), . 6.
} 
Tindak pidana terorisme adalah extra ordinary crime. Derajat "keluarbiasaan" ini pula yang menjadi salah satu alasan dikeluarkannya Perpu anti terorisme dan pemberlakuannya secara retroaktif untuk kasus bom Bali. Pengertian extra ordinary crime adalah pelanggaran berat HAM yang meliputi crime againts humanity dan goside (sesuai dengan Statuta Roma). Tindak pidana terorisme dimasukkan dalam extra ordinary crimedengan alasan sulitnya pengungkapan karena merupakan kejahatan transboundarydan melibatkan jaringan internasional. Perkembangan kejahatan internasional (international crime) memasuki abad 21 tampak semakin meningkat dan sudah merupakan pembahasan di kalangan masyarakat internasional dan juga telah dijadikan agenda PBB. Perkembangan tersebut membuktikan bahwa setiap kejahatan lokal atau nasional yang memiliki aspek internasional selalu akan menjadi perhatian masyarakat internasional baik melalui PBB maupun melalui lembaga-lembaga internasional non $\mathrm{PBB} .{ }^{32}$

Indonesia sebagai negara hukum, dalam penegakan hukum terhadap tindak pidana tertentu khususnya tindak pidana terorisme sangat mengutamakan landasan peraturan perundang-undangan yang bercirikan kepastian hukum dan keadilan. Pemberlakuan UU No.15 Tahun 2003, semakin menampakkan kelemahankelemahannya ketika diterapkan dalam praktek di lapangan.Namun demikian seiring perkembangan ilmu pengetahuan dan teknologi, dalam dunia kriminalpun mengikuti perkembangan hal ini dibuktikan dengan jenis-jenis kejahatan baru, yang apabila di tahun 1990-an masih dibicarakan tentang kejahatan komputer, tetapi di tahun 2000-an sudah dibicarakan tentang kejahatan cyber. ${ }^{33}$ Pergeseran dan

\footnotetext{
${ }^{32}$ Romli Atmasasmita, dkk, Naskah Akademik Perubahan UU No. 15 Tahun 2003, (Jakarta: BPHN, 2011), . 6.

33 Komariah Emong, Dampak Ilmu Pengetahuan dan Teknologi Terhadap Pembentukkan Asas-Asas Hukum Pidana, Makalah
}

perkembangan hukum pidana dan asas hukum pidana di Indonesia dari konvensional kearah modern harus disadari oleh pemerintah sebagai pembuat UU untuk mengantisipasi langkah yang harus diambil dalam menyikapi tindak pidana yang tidak lagi umum sifatnya. Pergeseran tersebut ditandai dengan modus operandi yang dilakukan secara acak (random) dan bersifat nomaden (berpindah-pindah). ${ }^{34}$

Penggunaan Perpu No. 2 Tahun 2002 didasarkan pada pertimbangan bahwa terjadinya terorisme di berbagai tempat di Indonesia telah menimbulkan kerugian baik materil maupun immateril serta menimbulkan ketidak amanan bagi masyarakat oleh karena itu setelah menjadi UUNo. 15 Tahun 2003, telah menjadi ketentuan payung dan bersifat koordinatif (coordinating act) terhadap peraturan perundang-undangan lainnya yang berkaitan dengan pemberantasan tindak pidana terorisme. UUNo. 15 Tahun 2003 menegaskan bahwa tindak pidana yang bertujuan politik sehingga pemberantasannya dalam wadah kerjasama bilateral dan multilateral dapat dilaksanakan secara lebih efektif. Tersangka atau terdakwa mendapat perlindungan khusus terhadap hak asasinya (safe guarding rules) dan juga diatur tentang ancaman sanksi pidana minimum khusus untuk memperkuat fungsi penjeraan terhadap pelaku tindak pidana terorisme. Setiap peristiwa yang dilakukan dengan menggunakan kekerasan atau ancaman kekerasan terhadap keselamatan jiwa manusia tanpa pandang bulu terhadap korbannya.

\section{Kebijakan Hukum Pidana Dalam Penanggulangan Tindak Pidana Terorisme}

disampaikan pada Seminar Asas-Asas Hukum Pidana Nasional, Oleh BPHN, bekerja sama dengan FH Universitas Diponegoro, Semarang, 26-27 April 2004.

${ }^{34}$ Romli Atmasasmita, dkk, Naskah Akademik Perubahan UU No. 15 Tahun 2003, (Jakarta: BPHN, 2011), . 11. 
1. Pembaharuan Hukum Pidana Berdasarkan Ideologi Pancasila

Pancasila, dalam konteks masyarakat bangsa yang plural dan dengan wilayah yang luas, harus dijabarkan untuk menjadi ideologi kebangsaan yang menjadi kerangka berpikir (the main of idea), kerangka bertindak (the main of action), dan dasar hukum (basic law) bagi segenap elemen bangsa. Namun, dalam kerangka pluralitas dan multikulturalisme tidak dinafikan dan dihalangi hidupnya ideologi kelompok yang sifatnya lebih terbatas selama tidak bertentangan dengan nilainilai Pancasila. Istilah ideologi berasal dari kata idea dan logos. Idea berarti gagasan, konsep, pengertian dasar, ide-ide dasar, cita-cita. kata idea berasal dari bahasa Yunani, eidos yang berarti bentuk atau idein yang berarti melihat. Idea dapat di artikan sebagai cita-cita, yaitu cita-cita yang bersifat tetap dan akan dicapai dalam kehidupan nyata. Cita-cita ini pada hakikatnya merupakan dasar, pandangan, atau faham yang diyakini kebenarannya. Logos berarti ilmu. secara harfiah, ideologi berarti ilmu pengetahuan tentang ide-ide (the science of ideas), atau ajaran-ajaran tentang pengertian dasar. ${ }^{35}$

Pancasila sebagai dasar negara dan pandangan hidup sekaligus juga merupakan ideologi negara. Sebagai ideologi negara berarti bahwa pancasila merupakan gagasan dasar yang berkenaan dengan kehidupan negara. Sebagaimana setiap ideologi memiliki konsep mengenai wujud masyarakat yang dicita-citakan, begitu juga dengan ideologi pancasila. Masyarakat yang dicita-citakan dalam ideologi pancasila adalah masyarakat yang dijiwai dan mencerminkan nilai-nilai dasar yang terkandung dalam Pancasila, yaitu masyarakat yang beriman dan bertaqwa kepada Tuhan serta bertoleransi, menjunjung tinggi nilai-nilai kemanusiaan, masyarakat yang bertsatu dalam suasana perbedaan, berkedaulatan rakyat dengan

\footnotetext{
${ }^{35}$ Sugito, A.T., dkk, Pendidikan Pancasila, (Semarang: Unnes Press, 2008), . 3.
}

mengutamakan musyawarah, serta masyarakat yang berkeadilan sosial. Hal itu berarti bahwa pancasila bukan hanya sesuatu yang bersifat statais melandasi berdirinya negara Indonesia, akan tetapi Pancasila juga membawakan gambaran mengenai wujud masyarakat tertentu yang diinginkan serta prinsip-prinsip dasar yang harus diperjuangkan untuk mewujudkannya. ${ }^{36}$

Ideologi Pancasila menjunjung tinggi persatuan bangsa dengan menempatkan terwujudnya persatuan bangsa itu di atas kepentingan pribadi, kelompok, atau golongan. Kerakyatan yang dipimpin oleh hikmah kebijaksanaan dalam permusyawaratan perwakilan. Pancasila sebagai ideologi membawakan nilai-nilai tertentu yang digali dari realitas sosiobudaya bangsa Indonesia. Oleh karena itu, ideologi Pancasila membawakan kekhasan tertentu yang membedakannya dengan ideologi lain. Kehidupan bermasyarakat dan bernegara yang didasarkan pada prinsip demokrasi dengan penentuan keputusan bersama yang diupayakan sejauh mungkin melalui musyawarah untuk mencapai kata mufakat.

Dalam hal pembentukan hukum yang dibuat haruslah disesuaikan dengan perkembangan dinamika masyarakat dan memperhatikan aspek keadilan ${ }^{37}$ dan memberikan perlindungan untuk menciptakan tertib hukum, di sinilah fungsi hukum sebagai aturan. Hal ini sesuai dengan landasan teori sociological jurisfrudence dari Roscoe Pound yang menekankan bahwa hukum merupakan alat

\footnotetext{
${ }^{36}$ Sugito, A.T., dkk, Pendidikan Pancasila, . 4.

${ }^{37}$ Bahwa keadilan adalah kebajikan utama dalam institusi sosial, sebagaimana kebenaran dalam sistem pemikiran. Suatu teori betapapun elegan dan ekonomisnya harus ditolak atau direvisi jika ia tidak benar, demikian juga hukum dan institusi tidak peduli betapapun efesien dan rapinya harus direformasi atau dihapuskan jika tidak adil. Lihat, John Rawls, Teori Keadilan: Dasar-Dasar Filsafat Politik Hukum Mewujudkan Kesejahteraan Sosial Dalam Negara, Terjemahan: Uzair Fauzan dan Heru Prasetyo, (Yogyakarta: Pustaka Pelajar, 2011), . 3 .
} 
untuk membangun masyarakat (law as a tool of social engineering), sejalan dengan pemikiran Roscoe Pound ini maka, Eugen Erlich mengajukan suatu konsepsi tentang hukum yang hidup dengan arti hukum yang demikian tidak ditemukan di dalam bahan-bahan hukum formal melainkan dalam masyarakat. ${ }^{38}$ Sistem hukum menurut Lawrence M. Friedman dalam teori "Legal System" menyatakan bahwa komponen dari sistem hukum itu meliputi tiga elemen yaitu: ${ }^{39}$

a. Substansi hukum (substance rule of the law), di dalamnya melingkupi seluruh aturan baik yang tertulis maupun yang tidak tertulis, baik yang hukum material maupun hukum formal;

b. Struktur hukum (structure of the law), melingkupi pranata hukum, Aparatur hukum dan sistem penegakan hukum. Struktur hukum erat kaitannya dengan sistem peradilan yang dilaksanakan oleh aparat penegak hukum, dalam sistem peradilan pidana, aplikasi penegakan hukum dilakukan oleh penyidik, penuntut, hakim dan advokat; dan

c. Budaya hukum (legal culture), merupakan penekanan dari sisi budaya secara umum, kebisaaan-kebisaaan, opiniopini, cara bertindak dan berpikir, yang mengarahkan kekuatan sosial dalam masyarakat.

Hukum sebagai sarana pembaharuan masyarakat (law as a tool of social engeneering), menurut Mochtar

38 Lili Rasjidi dan I. B. Wyasa Putra,Hukum...., 79.

${ }^{39}$ Lawrence M. Friedman,The Legal Sistem; A Social Scince Prespective, (New York: Russel Sage Foundation, 1975), . 12-16.
Kusumaatmadja, dituangkan dalam konsep hukum pembangunan, yang dinyatakan: ${ }^{40}$

"Sarana pembaharuan masyarakat didasarkan kepada anggapan bahwa adanya keteraturan atau ketertiban dalam usaha pembangunan dan pembaharuan itu merupakan suatu yang diinginkan atau dipandang (mutlak) perlu. Anggapan lain yang terkandung dalam konsepsi hukum sebagai sarana pembaharuan adalah bahwa hukum dalam arti kaidah atau peraturan hukum memang bisa berfungsi sebagai alat (pengatur) atau sarana pembangunan dalam arti penyalur arah kegiatan manusia ke arah yang dikehendaki oleh pembangunan dan pembaharuan".

Perubahan yang teratur melalui prosedur hukum baik yang berwujud peraturan perundang-undangan atau keputusan badan-badan peradilan lebih baik daripada perubahan yang tidak teratur dengan menggunakan kekerasan semata. Karena baik perubahan maupun ketertiban (keteraturan) merupakan tujuan kembar dari masyarakat yang sedang membangun, hukum menjadi suatu alat yang tidak dapat diabaikan dalam proses pembangunan. ${ }^{41}$

Hukum merupakan suatu alat untuk memelihara ketertiban dalam masyarakat. Mengingat fungsinya sifat hukum, pada dasarnya adalah konservatif artinya,hukum bersifat memelihara dan mempertahankan yang telah tercapai. Fungsi demikian diperlukan dalam setiap masyarakat, termasuk masyarakat yang sedang membangun, karena di sini pun ada hasilhasil yang harus dipelihara, dilindungi dan diamankan. Akan tetapi, masyarakat yang sedang membangun yang dalam difinisi kita berarti masyarakat yang sedang berubah cepat, hukum tidak cukup memiliki memiliki fungsi demikian saja,juga harus dapat membantu proses perubahan masyarakat itu. Pandangan yang kolot tentang hukum yang menitikberatkan fungsi pemeliharaan ketertiban dalam arti statis, dan menekankan sifat konservatif

\footnotetext{
${ }^{40}$ Mochtar Kusumaatmadja,Konsep... 20

${ }^{41}$ Mochtar Kusumaatmadja,Konsep., . 20.
} 
dari hukum, menganggap bahwa hukum tidak dapat memainkan suatu peranan yang berarti dalam proses pembaharuan. ${ }^{42}$

Kejahatan merupakan gejalan universal, artinya tidak hanya menjadi masalah nasional tetapi juga menjadi masalah yang ada dimana-mana. Karena kejahatan mendatangkan kerugian di dalam kehidupan masyarakat, maka terhadap pelaku kejahatan perlu dilakukan pemberian sanksi atau hukuman yang setimpal, dan untuk itu perlu suatu proses untuk menetapkan bahwa suatu perbuatan itu adalah kejahatan oleh suatu lembaga yang berwenang dengan menjatuhkan sanksi pidana. Pembaharuan hukum pidana dalam konsep politik kriminal menurut Sudarto, mempunyai tiga arti, yaitu: ${ }^{43}$

a. Dalam arti sempit, ialah keseluruhan asas dan metode yang menjadi dasar dari reaksi terhadap pelanggaran hukum yang berupa pidana;

b. Dalam arti luas, ialah keseluruhan fungsi dari aparatur penegak hukum,termasuk di dalamnya cara kerja pengadilan dan polisi;

c. Dalam arti paling luas ialahkeseluruhan kebijakan, yang dilakukan melalui perundang-undangan danbadanbadan resmi, yang bertujuan untuk menegakkan normanormasentral dari masyarakat".

Menurut Thomas Dye menyebutkan kebijakan sebagai pilihan pemerintah untuk melakukan atau tidak melakukan sesuatu (whatever government chooses to do or not to do). Kebijakan atau upaya penanggulangan kejahatan pada hakikatnya merupakan bagian integral dari upaya perlindungan masyarakat (social defence) dan upaya mencapai kesejahteraan masyarakat (social welfare).

\footnotetext{
${ }^{42}$ Mochtar Kusumaatmadja, KonsepKonsep... . 14.

${ }^{43}$ Sudarto, Hukum dan Hukum Pidana, (Bandung: Alumni, 1981), . 38.
}

Tujuan akhir dari politik kriminal ialah perlindungan masyarakat untuk mencapai kesejahteraan masyarakat. Kebijakan kriminal harus ditempuh dengan pendekatan yang integral yaitu ada keseimbangan sarana penal dan non penal. Dilihat dari aspek politik kriminal kebijakan paling strategis melalui apa yang dinamakan dengan sarana non penal. ${ }^{44}$ Kebijakan hukum pidana melalui konsep pidana modern yang diharapkan dapat menjawab ekspektasi dan rasa keadilan. ${ }^{45}$

\section{Kebijakan Penanggulangan Tindak Pidana Teorisme}

Pemberantasan tindak pidana terorisme di Indonesia bukan merupakan masalah hukum dan penegakan hukum semata karena juga terkait masalah sosial kenegaraan, budaya, ekonomi dan juga keterkaitannya dengan pertahanan negara, terdapat banyak cara atau upaya yang dapat dilakukan oleh masyarakat maupun negara untuk melakukan pemberantasan terorisme dan penaggulangan terhadap kejahatan lainnya. Namun usaha tersebut tidak dapat menghapuskan secara tuntas kejahatan yang ada, mungkin hanya dapat mengurangi kuantitasnya. Kebijakan memerangi terorisme harus senantiasa berdasarkan beberapa prinsip, yaitu: ${ }^{46}$

a. Perlindungan kebebasan sipil serta penghargaan danperlindungan hak-hak individu. Pembatasan terhadap hak-hak demokratik sepertiitu hanya dapat dilakukan terhadap hak yang tidak termasuk ke dalam nonderogable rights, dalam jangka waktu sementara dan untuk kepentingan publik; dan

\footnotetext{
${ }^{44}$ Barda Nawawi Arief, Kebijakan... Op.Cit., . 33.

45 Lili Rasjidi dan Bernard Arief Sidharta,Filsafat Hukum Mazhab dan Refleksinya, (Bandung: Remaja Rosdakarya, 1994), . 25-26.

${ }^{46}$ Budi Hardiman., F, Terorisme... Op.Cit., . $50-51$.
} 
b. Pembatasan dan pencegahan penyalahgunaan kekuasaan oleh negara. Inidapat dilakukan dengan menerapkan sepenuhnya prinsip checks and balancesdalam proses perumusan dan pengambilan keputusan, spesialisasi fungsi institusi pelaksana kebijakan dan tersedianya mekanisme akuntabilitas publik bagi pelaksana kebijakan.

Pengaturan tentang tindak pidana terorisme meliputi 2 (dua) aspek yaitu pencegahan (anti) dan pemberantasan (contra). Dalam hal pencegahan, kegiatan terorisme tidak dapat dilakukan hanya melalui pendekatan hukum saja melainkan meliputi segala aspek masyarakat. Tindakan teror (biasanya) dilatarbelakangi perasaan diperlakukan secara tidak adil, ketertindasan dan kepercayaan tertentu, sehingga pencegahannya harus dapat mengeliminasinya dengan mewujudkan keadilan serta pembebasan dari kemiskinan yang pada tataran operasional dapat dilakukan dengan deteksi dini (early warning system). Sedangkan peraturan kontra terorisme bertujuan untuk memberantas, mengungkap dan menangani kasus tindak pidana teror dan pelakunya berupa penetapan tindakan-tindakan yang termasuk dalam tindak pidana teror, prosedur penanganan, mulai penyelidikan hingga peradilan, serta sanksi yang diancamkan kepada pelaku teror. ${ }^{47}$

Beberapa peristiwa pengeboman yang terjadi di sejumlah wilayah Indonesia, terutama Bom Bali, menjadi latar belakang atau momentum menentukan dibentuknya payung hukum yang mengatur tentang pemberantasan tindak terorisme. Terdapatnya ratusan korban, baik warga negara Indonesia maupun warga negara asing menempatkan Indonesia pada situasi tidak memiliki pilihan lain kecuali secara serius

\footnotetext{
${ }^{47}$ Budi Hardiman., F, Terorisme.... 62-63.
}

menanggulangi terorisme. Atas desakan berbagai pihak, akhirnya pemerintah menerbitkan Peraturan Pemerintah Pengganti Undang-Undang (Perppu) No. 1 dan Perppu No. 2 Tahun 2002 tentang Pemberantasan Tindak Pidana Terorisme. ${ }^{48}$ Sebenarnya, saat itu DPR telah memiliki Rancangan Undang-Undang Antiterorisme yang sedang dalam tahap pembahasan, oleh karena pembahasannya membutuhkan waktu yang panjang dan guna menghindari kekosongan hukum, Perppu No.1 Tahun 2002 disahkan pemerintah bersama DPR menjadi undang-undang melalui UndangUndang No.15 Tahun 2003. ${ }^{49}$ Selain sebagai Undang-Undang khusus pidana materiel, UU No. 15 Tahun 2003 pun merupakan Undang-Undang khusus pidana formil.

Upaya penanggulangan kejahatan pada hakekatnya merupakan suatu usaha untuk pengamanan masyarakat (social defence) agar masyarakat dapat terhindar dari kejahatan atau setidak-tidaknya mengendalikan kejahatan yang terjadi agar berada dalam batas-batas toleransi masyarakat. Terhadap masalah kemanusiaan dan masalah kemasyarakatan ini telah banyak usaha-usaha yang dilakukan untuk menanggulanginya. Salah satu usaha penanggulangan kejahatan yang dilakukan adalah dengan menggunakan sarana penal yaitu menggunakan hukum pidana dengan sanksinya yang berupa pidana. Penanggulangan kejahatan dengan menggunakan hukum pidana merupakan cara yang paling tua, setua peradaban manusia itu sendiri. ${ }^{50}$ Akan tetapi ini tidak bararti bahwa penggunaan pidana sebagai salah satu cara untuk menanggulangi kejahatan. Langkah represif yang

${ }^{48}$ T. Nasrullah, Tinjauan Yuridis Aspek Hukum Materil Maupun Formil Terhadap UU No. 15 Tahun 2003 tentang Pemberantasan Tindak Pidana Terorisme, Jurnal Kriminologi Indonesia Vol. 4 No. 1 September 2005, . 65-67.

${ }^{49}$ Todung Mulya Lubis, Jalan Panjang Hak Asasi Manusia, (Jakarta: Gramedia Pustaka Utama, 2005), . 261.

${ }^{50}$ Muladi dan Barda Nawawi Arief, Teori.., . 149. 
dilakukan oleh pemerintah dalam rangka melakukan penanggulangan terhadap tindak pidana terorisme adalah sebagai berikut: $^{51}$
a. Pembentukan
Badan
Penanggulangan Tindak Pidana
Terorisme, serta pembentukan satuan khusus sebagailangkah pemberantasan tindak pidana terorisme;

b. Penyerbuan terhadap tempat persembunyian pelaku terorisme;

c. Penjatuhan sanksi pidana yangtegas terhadap pelaku tindak pidanaterorisme yang telah terbukti bersalah berdasarkan bukti-buktiyang ada.

Kebijakan untuk membuat peraturan hukum pidana yang baik pada hakekatnya tidak dapat dilepaskan dari tujuan penanggulangan kejahatan. Jadi kebijakan atau politik hukum pidana juga merupakan bagian politik kriminal, maka politik hukum pidana identik dengan pengertian "kebijakan penanggulangan kejahatan dengan hukum pidana". Usaha penanggulangan kejahatan dengan hukum pidana pada hakekatnya juga merupakan bagian dari usaha penegakan hukum (khususnya penegakan hukum pidana). Oleh karena itu, sering pula dikatakan, bahwa politik atau kebijakan hukum pidana juga merupakan bagian dari kebijakan penegakan hukum (law enforcement policy). Salah satu cara menanggulangi terorisme adalah dengan menggunakan hukum pidana (penal policy). Menurut Marc Ancel, penal policy didefinisikan sebagai "suatu ilmu sekaligus seni yang pada akhirnya mempunyai tujuan praktis untuk memungkinkan peraturan hukum positif dirumuskan secara lebih baik" yang dimaksud dengan peraturan hukum positif adalah peraturan perundang-undangan pidana. Dengan

\footnotetext{
${ }^{51}$ Hery Firmansyah, Upaya., . 391.
}

demikian istilah "penal policy" menurut Marc Ancel adalah sama dengan istilah kebijakan atau politik hukum pidana. ${ }^{52}$

a.

Pembaharuan hukum pidana harus dilakukan dengan pendekatan kebijakan, karena memang pada hakikatnya pembaharuan hukum pidana hanya merupakan bagian dari suatu langkah kebijakan atau "policy" (yaitu bagian dari politik hukum/penegakan hukum, politik hukum pidana, politik kriminal dan politik sosial). Dalam setiap kebijakan (policy) terkandung pula pertimbangan nilai. Oleh karena itu, pembaharuan hukum pidana harus pula berorientasi pada pendekatan nilai. ${ }^{53}$

Dalam perkembangan masyarakat saat ini, upaya-upaya nonpenal dalam menanggulangi kejahatan termasuk tindak pidana terorisme telah menjadi bahan pertimbangan dalam melakukan kebijakan yang lebih efisien, karena diakui sebagai upaya yang dapat mengeluarkan biaya yang relatif lebih kecil, namun dengan hasil yang maksimal. Dalam perkembangannya, kebijakan kriminal untukmemberantas kejahatan, berkembang ke arah tindakan-tindakan proaktif yang ternyata lebih murah dan menjanjikan hasil yang lebih baik.Tanggung jawab pencegahan kejahatan diperluas mencakup lembagalembaga dan individu-individu di luar sistem peradilan pidana. Keterlibatan masyarakat dalam mencegah kejahatan dapat berupa informal yang dapat menyelesaikan kasus-kasus kejahatan di sekolah, tempat kerja, atau lingkungan sosial yang dilakukan oleh anggota masyarakat biasa. Upaya nonpenal memusatkan perhatian pada campur tangan sosial, ekonomi, dan berbagai area kebijakan publik dengan maksud

\footnotetext{
${ }^{52}$ Barda Nawawi Arief, Beberapa Aspek Kebijakan Penegakan dan Pengembangan Hukum Pidana, (Bandung: Citra Aditya Bakti, 1998), . 23

${ }^{53}$ Barda Nawawi Arief, Pokok-Pokok Pemikiran (Ide Dasar) Asas-Asas Hukum Pidana Nasional. Makalah pada Seminar Nasional BPHN, Semarang, 2004, . 14.
} 
mencegah terjadinya kejahatan. Bentuk lain dari keterlibatan masyarakat tampak dari upaya pencegahan kejahatan yang terpusat pada akar kejahatan atau pencegahan situasional dan peningkatan kapasitas masyarakat dalam penggunaan sarana kontrol sosial informal. Perkembangan terakhir mengarah pada peningkatan keseimbangan pencegahan kejahatan yang berorientasi pada pelaku (offender-centered crime prevention) dan yang berorientasi pada korban (victimcentered crime prevention). ${ }^{54}$

Upaya-upaya nonpenal sebagaimana dikemukakan di atas, tentu saja dapat diterapkan dalam upaya pencegahan tindak pidana terorisme yang terjadi di Indonesia. Dalam menentukan upaya nonpenal yang akan diberlakukan dalam rangka pencegahan tindak pidana terorisme, tentu saja harus memperhatikan kondisi-kondisi yang menjadi akar persoalan terorisme. Upaya deradikalisasi merupakan salah satu alternatif yang dapat diterapkan dalam penanggulangan tindak pidana terorisme di Indonesia.Oleh sebab itu, adanya program deradikalisasi terorisme merupakan salah satu program yang dapat membantu upaya pemberantasan terorisme.Pemerintah melalui Badan Nasional Penanggulangan Terorisme (BNPT) menggalakkan upaya deradikalisasi terorisme. Upaya ini ditujukan untuk mengimbangi upaya pemberantasan terorisme melalui cara konvensional, misalnya penggerebekan, penangkapan, sampai dengan penghentian aksi teror. Deradikalisasi terorisme ini dilakukan sebagai upaya pencegahan dini, sehingga mematahkan potensi berkembangnya gerakan terorisme tersebut.

\section{Deradikalisasi Penanggulangan Tindak Pidana Terorisme}

Deradikalisasi berasal dari kata radikal yang berarti secara mendasar yaitu

54 Muladi, Aspek Internasional Kebijakan Kriminal Non Penal, Makalah pada Seminar Nasional Pendekatan Nonpenal dalam Penanggulangan Kejahatan, Fakultas Hukum Undip, Semarang, 1996. “perubahan". Sementara deradikalisasi adalah suatu upaya pencegahan yang dilakukan agar para narapidana dan mantan Narapidana serta pihak lain yang berpotensi terlibat tindak pidana untuk tidak melakukan atau tidak melakukan kembali kekerasan atau aksi terorisme. Pengalaman menunjukan bahwa dengan ditangkap, ditahan dan dihukum melalui sidang Pengadilan tidak menyurutkan atau menghentikan para pelaku terorisme untuk melakukan kembali aksi kegiatan kekerasan atau terorisme,dan sebaliknya dengan kegiatan penindakan atau penegakan hukum dan disertai kegiatan deradikalisasi terhadap para narapidana dan mantan narapidana serta pihak lain yang berpotensi untuk terlibat, menunjukan hasil yang positif(signifikan) guna mencegah terjadinya kembali aksi kekerasan atau terorisme karena mereka sudah sadar untuk kembali pada kehidupan yang sebenarnya. ${ }^{55}$

Setelah terjadinya penyerangan terhadap gedung World Trade Center dan Pentagon di Amerika Serikat dengan menggunakan "pesawat sebagai misil", pada tanggal 11 September 2001, isu terorisme kembali menjadi hangat. Propaganda perang melawan terorisme segera dihembuskan, dan akhirnya terorisme, hingga saat ini, telah menjadi pusat perhatian banyak pihak di seluruh dunia. ${ }^{56}$ Untuk para aparat penegak hukum, terorisme kemudian telah menjadi objek penanganan yang serius. Penanganan terhadap pelaku tindak pidana terorisme yang dianggap atau telah terbukti menjadi pelaku tindak pidana terorisme biasanya lebih cenderung mengarah kepada penanganan yang represif. Apalagi di dalam pemberitaan di media-media massa, televisi atau surat kabar, yang lebih sering terangkat adalah berita penanganan tindak pidana terorisme yang dilakukan secara represif, seperti melalui penggeledahan (penggerebekan), pengepungan atau

\footnotetext{
${ }^{55}$ Romli Atmasasmita, dkk, Naskah...., . 78.

${ }^{56}$ James Petras, Zionisme dan Keruntuhan Amerika, (Jakarta: Zahra, 2009), . 133.
} 
bahkan penembakan. Atau, kalaupun beritanya tentang proses hukum di pengadilan terhadap para terdakwa tindak pidana terorisme, maka yang lebih sering terungkap adalah tentang penjatuhan putusan pidana yang seberat-beratnya terhadap para terdakwa itu tersebut.

Pemikiran bahwa tindak pidana terorisme lebih sering terdengar ditangani secara represif seperti yang baru dijelaskan di atas, tentu merupakan hal yang wajar. Pemikiran seperti itu, jika dihubungkan dengan falsafah yang ada di dalam hukum pidana, juga ada tempatnya sendiri, yaitu pada falsafah pemidanaan yang bertujuan untuk membalas (teori retributif) atau membuat jera serta mencegah terulangnya suatu tindak pidana (teori relatif). Namun demikian, pemikiran tersebut tidaklah lengkap. Perlu juga diketahui bahwa tindak pidana terorisme tidak melulu harus dihubungkan dengan penanganan yang represif. Ada kalanya, dengan beberapa alasan tertentu, justru tindak pidana terorisme ditangani secara lebih"humanis". Salah satu bentuk dari upaya penanganan secara lebih "humanis" itu adalah apa yangdikenal dengan "program deradikalisasi terorisme". 57

Deradikalisasi dapat dipahami sebagai segala upaya untuk menetralisasi paham-paham radikal melalui pendekatan interdisipliner, seperti agama, psikologi, hukum serta sosiologi, yang ditujukan bagi mereka yang dipengaruhi paham radikal. Sebagai rangkaian program yang berkelanjutan, deradikalisasi ini meliputi banyak program yang terdiri dari reorientasi motivasi, reedukasi, resosialisasi, serta mengupayakan kesejahteraan sosial dan kesetaraan dengan masyarakat lain bagi mereka yang terlibat dengan tindak pidana terorisme (para terpidana tindak pidana

\footnotetext{
${ }^{57}$ Endra Wijaya, Peranan Putusan Pengadilan Dalam Program Deradikalisasi Terorisme di Indonesia, Jurnal Yudisial Vol.III/No2/Agustus/2010, . 110.
}

terorisme). ${ }^{58}$ Apabila

program deradikalisasi ingin ditempatkan sebagai suatu program penanganan tindak pidana terorisme yang lebih "humanis", maka unsur hukum yang merupakan bagian dalam rangkaian program deradikalisasi tampaknya perlu pula coba diupayakan menjadi sarana yang tidak semata-mata represif. Hal itu berarti bahwa dalam program deradikalisasi unsur hukum juga harus dapat difungsikan sebagai suatu sarana yang dapat mengubah secara perlahan-lahan paham radikal yang ada di dalam diri terpidana tindak terorisme. Secara teoretis, fungsi hukum seperti itu sebenarnya telah lama dikenal, yaitu dengan menempatkan hukum sebagai saranauntuk mengubah pemahaman dan perilaku masyarakat. $^{59}$

Deradikalisasi merupakan segala upaya untuk menetralisir paham-paham radikal melalui pendekatan interdisipliner, seperti hukum, psikologi, agama dan sosial budaya bagi mereka yang dipengaruhi paham radikal dan/atau pro kekerasan.Sebagai sarana untuk mengubah pemahaman dan perilaku masyarakat, maka hukum dipahami sebagai cara-cara untuk mempengaruhi masyarakat dengan sistem yang teratur dan direncanakan terlebih dahulu. Di sini berarti hukum itu diharapkan dapat memainkan pengaruhnya, baik langsung maupun tidak langsung, dalam mendorong terjadinya perubahan pemahaman dan perilaku dari individu-individu yang ada di dalam masyarakat. ${ }^{60}$ Wujud hukum yang dapat difungsikan sebagai sarana untuk mengubah pemahaman dan perilaku masyarakat tentu sangat beragam. Namun, khusus untuk konteks penanganan tindak pidana terorisme melalui program deradikalisasi, maka harus diakui bahwa di

\footnotetext{
${ }^{58}$ Petrus Reinhard Golose,

Deradikalisasi...50 .

${ }^{59}$ Soerjono Seokanto, Pokok-Pokok Sosiologi Hukum, RajaGrafindo Persada, Jakarta, 2003, . 122 dan . 135.

${ }^{60}$ Soerjono Seokanto, Pokok-Pokok Sosiologi Hukum, RajaGrafindo Persada, Jakarta, 2003, . 122.
} 
Indonesia belum ada instrumen hukum yang komprehensif yang bisa dijadikan sebagai dasar (payung hukum) dari program deradikalisasi. ${ }^{61}$

\section{Kesimpulan}

Kejahatan terorisme merupakan hasil dari akumulasi beberapa faktor, bukan hanya oleh faktor psikologis, tetapi juga ekonomi, politik, agama, sosiologis, dan masih banyak lagi yang lain. Karena itu terlalu simplistik kalau menjelaskan suatu tindakan terorisme hanya berdasarkan satu penyebab misalnya psikologis. Konflik etnik, agama dan ideologi, kemiskinan, tekanan modernisasi, ketidakadilan politik, kurangnya saluran komunikasi dana, tradisi kekejaman, lahirnya kelompokkelompok revolusioner, kelemahan dan ketidakmampuan pemerintah, erosi kepercayaan daripada rezim, dan perpecahan begitu mendalam di antara pemerintahan dan elit politik juga menjadi penyebab lahirnya terorisme.

Muatan-muatan baru tersebut menjadi pro dan kontra di berbagai kalangan karena sebagian besar pasalpasalnya bertentangan dengan hak asasi manusia. Yang menjadi permasalahan utama adalah mengenai jangka waktu penangkapan dan penahanan dalam RUU Pemberantasan Tindak Pidana Terorisme. Terdapat perbedaan jangka waktu penangkapan dan penahanan dari KUHAP, UU No. 15 Tahun 2013 tentang Pemberantasan Tindak Pidana Terorisme serta RUU Pemberantasan Tindak Pidana Terorisme. Jangka waktu yang semakin lama tersebut memperbesar kemungkinan terjadinya pelanggaran hak asasi manusia.

Selain itu kewenangan penyidik di dalam menangkap, menahan, menyadap telepon yang terdapat di dalam RUU Pemberantasan Tindak Pidana Terorisme perlu untuk di batasi dan diperketat lagi agar tidak terjadi penyalahgunaan wewenang dan pelanggaran terhadap hak

\footnotetext{
${ }^{61}$ Petrus Reinhard Golose, Deradikalisasi...., .86.
}

asasi manusia yang dilakukan oleh penyidik tersebut.

\section{DAFTAR PUTAKA}

A.T , Sugito,.., dkk, Pendidikan Pancasila, Unnes Press, Semarang, 2008

Abbas, Hafid Beyond Terrorism: Perspektif Indonesia, Pustaka Sinar Harapan, Jakarta, 2002

Abidin , Zainal, Hukum Pidana I, Sinar Grafika, Jakarta, 2007

Afdal dkk, Islam dan Radikalisme di Indonesia, Jakarta, LIPI Press, 2005

Ali Syafaat , Muchamad, Terorisme, Definisi, Aksi dan Regulasi, Imparsial, Jakarta, 2003

Amin, Ma'ruf, Meluruskan Makna Jihad Mencegah Terorisme, Tim Penanggulangan Terorisme MUI, Jakarta, 2007

Atmasasmita , Romli, Kasus Terorisme Di Indonesia Berdasarkan UndangUndang Nomor 15 Tahun 2003 Tentang Pemberantasan Tindak Pidana Terorisme, Makalah pada Seminar Penanganan Terorisme Sebagai Tindak Pidana Khusus, Jakarta 28 Juni 2004,

Atmasasmita ,Romli, dkk, Naskah Akademik Perubahan UU No. 15 Tahun 2003, BPHN, Jakarta, 2011

Atmasasmita,,Romli Pengantar Hukum Pidana Internasional, Rafika Aditama, Bandung, 2000

Azra , Azyumardi, Memahami Gejala Fundamentalisme, Jurnal Ulumul Qur'n, No. 3 Vol. IV 1993

Cristine S.T. Kansil , C.S.T. Kansil, Pokok-Pokok Hukum Pidana, Pradnya Paramita, Jakarta, 2007

Friedman , Lawrence M.,The Legal Sistem; A Social Scince Prespective, Russel Sage Foundation, New York, 1975

Garner, Bryan A., Black's Law Dictonary, Ninth Edition, West Publishing Co, St. Paul-Minn, 2009

Gunawan , Budi, Terorisme, Mitos dan Konspirasi, Forum Media Utama, Jakarta, 2006 
Hamzah, Andi , Asas-Asas Hukum Pidana, Rineka Cipta, Jakarta, 2008

Hardiman , F. Budi, Memahami Negativitas: Diskursus tentang Massa, Teror, dan Trauma, Kompas, Jakarta, 2005

Hasani ,Ismail dan Bonar Tigor Naipospos, Radikalisme Agama di Jabotabek dan Jawa Barat: Implikasinya Terhadap Jaminan Kebebasan Beragama/Berkeyakinan, Pustaka Msyarakat Stara, Jakarta, 2010

Hikam, Muhammad A.S., Deradikalisasi: Peran Masyarakat Sipil Indonesia Membendung Radikalisme, Jakarta: PT Kompas Media Nusantara, 2016

Loqman , Loebby, Analisis Hukum dan Perundang-undangan Kejahatan Terhadap Keamanan Negara di Indonesia, Universitas Indonesia Press, Jakarta, 1990

Lubis, Todung Mulya, Jalan Panjang Hak Asasi Manusia, Gramedia Pustaka Utama, Jakarta, 2005

Mertokusumo, Sudikno, Mengenal Hukum, Suatu Pengantar, Liberty, Yogyakarta, 1996

Moeljatno, Asas-Asas Hukum Pidana, Rineka Cipta, Jakarta, 2002

Muladi, Hakekat Terorisme dan Beberapa Prinsip Pengaturan dalam Kriminalisasi, tulisan dalam Jurnal Kriminologi Indonesia FISIP UI, Vol II No. 03 Desember 2002, Hal. 1.
Nasrullah, T. , Tinjauan Yuridis Aspek Hukum Materil Maupun Formil Terhadap UU No. 15 Tahun 2003 tentang Pemberantasan Tindak Pidana Terorisme, Jurnal Kriminologi Indonesia Vol. 4 No. 1 September 2005

Rasjidi , Lili dan Bernard Arief Sidharta,Filsafat Hukum Mazhab dan Refleksinya, Remaja Rosdakarya, Bandung, 1994

Remmelink, Jan, Hukum Pidana: Komentar Atas Pasal-Pasal Terpenting Dari Undang-Undang Hukum Pidana Belanda dan Padanannya Dalam Kitab UndangUndang Hukum Pidana Indonesia, Terjemahan: Tristam Pascal Moeliono, Gramedia Pustaka Utama, Jakarta, 2003

Rubiadi, A, Radikalisme Islam,Nahdatul Ulama Masa Depan Moderatisme Islam di Indonesia, Logung Pustaka, Yogyakarta, 2007

Shidarta, Moralitas Profesi Hukum: Suatu Tawaran Kerangka Berpikir, Rafika Aditama, Bandung, 2006

Sudarto, Hukum Pidana I, Badan Penerbit Universitas Diponegoro, Semarang, 1990

Wahid, Abdul, Kejahatan Terorisme Perspektif Agama, HAM dan Hukum, Rafika Aditama, Bandung, 2002 